\title{
Factors influencing social shopping behavior of fashion in Tehran apparel market
}

\author{
Mohammad Rahim Esfidani, Mohsen Nazari and Maryam Karimi Davijani*
}

Department of Business Management, Faculty of Management, University Of Tehran, Tehran, Iran

\begin{tabular}{l}
\hline C H R O N I C L E \\
\hline Article history: \\
Received February 28, 2014 \\
Received in revised format April \\
152014 \\
Accepted April 302014 \\
Available online \\
May 4 2014 \\
\hline Keywords: \\
Social shopping behavior of \\
fashion \\
Obsessed with fashion apparel \\
Materialism \\
Fashion Clothing Involvement
\end{tabular}
A B S T R A C T

\begin{abstract}
Social shopping behavior of fashion embraces various activities, direct/indirect complex and dynamic interpersonal happening during the process of buying fashion and causes customers' pleasure and satisfaction from purchasing intention, which in long-term helps sales improvement. This study has taken place in city of Tehran, Iran in order to assess the social purchase behavior of consumers and drivers in the field of fashion garments. Data analysis was performed using partial least squares. Research findings indicate a significant positive relationship between obsessed with fashion garments and the five dimensions of social shopping behavior. On the other hand, there is a positive and meaningful relationship between materialism and the need for uniqueness by consumers' involvement toward fashion apparel.
\end{abstract}

(C) 2014 Growing Science Ltd. All rights reserved

\section{Introduction}

Wear uniquely has been always an important part of life's identity. The way we dress not only influences the feeling towards our personality but also, it forms the attitude of other people toward our personality and social status. Therefore, the way of dressing expresses own personal identities (O'Cass, 2000). Clothes, in addition to its functional role in covering, are considered as one of the staples of fashion. Nowadays, fashion has become an interesting business; and annually, something more than a trillion dollars spent on clothing and footwear in the world. Shopping fashion garments, in addition to economic aspects also in terms of social plays essential role in most societies. Shopping is not only limited to spend money to buy goods, but also for many people, it is a fun activity. Since, it provides the opportunity to understand and to meet other people it is considered as a method for socializing (Holahan, 2007). In literature, shopping behaviors are depicted indirectly that social interactions and satisfaction of social needs during purchase by successful performance in marketing and sales are in connection, including having permanent customers for a store, positive attitude toward a store or brand, spend time and money to buy (Babin et al., 1994).

*Corresponding author

E-mail addresses: m.karimi.d@ut.ac.ir (M. Karimi Davijani) 
Social behaviors during purchase is the consumer supporter in purchase decision-making, and induce consumer a positive feelings like joy from buying (Chang et al., 2004; Reynolds \& Beatty, 2000). According to results of some research, social shopping behavior is associated with other important actions in the field of fashion and psycho-social components. In order to achieve marketing and sales targets, understanding consumers' social behaviors and drives, it is essential to recognize what motives stimulate consumers to do social activities during a purchase. On the other hand, researchers believe that mind involvement is a state of mind-psychology considered as an important factor in understanding consumer behavior and resource for explaining differences between consumers in both intellectual and practical aspect of decision-making. Mind involvement with fashion is an emotional reason that motivates consumers to purchase such fashion clothes, since they require to be update and attractive. Often, they have been purchased in accordance with the fashion not because of the need, but also for the enjoyment of the consuming experience (Lerkpollakarn \& Khemarangsan, 2007). Therefore, we can consider this variable as a driver of social shopping behavior and we may consider personal characteristics of the consumer such as materialism and the need for uniqueness as the aftermath of such involvement.

\section{Review of literature}

\subsection{Social shopping}

Numerous studies have emphasized that one of the important reasons for consumers to make purchases, is to communicate with others and satisfy social needs (Arnold and Reynolds, 2003; Dawson et al, 1990; Holahan, 2007; Westbrook and Black, 1985; Stone, 1954). Consumers during purchase exhibit extended range of social behaviors, like watching people and paying attention to appearances and others' clothing for entertainment, shopping skills exchange and such behaviors to draw attentions and to achieve social status (Kang, 2010); and for making purchase decision they collect both verbal and nonverbal cues (Phau \& Lo, 2004). These social behaviors make sense in the category of fashion; because, fashion has essentially symbolic and interactive meaning and plays essential role in a nonverbal and visual media in most of social environments (Kang, 2010).

Fashion purchase environments naturally include interpersonal and social interactions (Bloch et al., 1994; Cowan, \& Swann, 2004). According to Kang's definition, social shopping in the field of fashion is the behaviors of consumers during his interactions and exchanges with others throughout the process of buying fashion products. Social shopping is not limited only to the actual purchase of the product, but also involves interaction with other people, both verbal and non-verbal, presence or non-presence throughout the entire purchasing process (Kang, 2010). Kang considered 5 dimensions for in order to achieve a comprehensive understanding of the subject and to draw overview of social shopping. Also in this study, we use these categories to explain social shopping behavior in terms of fashion apparel. Below we describe the five aspects of social shopping in the fashion.

\subsubsection{Social Browsing}

Social Browsing is to explore for information about new fashions, and products which are popular among others. According to the basis of embrace and promoting innovation theory, the majority of consumers will accept the new products when they see the leaders bought these products (Rogers, 1976). Seeking information among friends and others via social search will help the consumers in decision-making process and by reducing the risk and perceived uncertainty associated with decision will aid them in purchase decision (Parsons, 2002). 


\subsubsection{Social Bonding}

It is stated as social ties to the community; time allocated for the togetherness, interaction with close friends and family during fashion purchase. Dependency theories mention that individuals want to reduce their loneliness by being with others (Murray, 1938). Fashion shopping is a tool to strengthen relations because in the processes prior to purchase, a lot of interactions between individuals occur (Kang, 2010). Social ties as the second dimension of social shopping behavior and inspire a positive feeling like pleasure, entertainment and recreation; previous studies show that this dimension is in connection with enjoyment values (Arnold \& Reynolds, 2003).

\subsubsection{Opinion Showing}

Expression of an opinion refers to demonstration of knowledge and skills, or giving information about fashion purchase to others. Consumers can affect others by verbal communication or nonverbal interactions. Based on the theory of opinion leadership in Fashion, most of the consumers that affect the decisions of others about fashion (Opinion leaders in fashion), they enjoy to be known by their types of purchase (Bertrandias \& Goldsmith, 2006). Some of consumers believe when they wear a new type and pass their purchase information to others, they will be praised. Belief plays an important role in opinion leadership in the field of fashion (Flynn et al., 1996).

\subsubsection{Power shopping}

Pursuit of power is that people during the process of buying fashion are seeking to influence others. Tober believes that some of consumers during purchase may seek for attention and respect from others. Consumers go to stores to buy where they know they will be considered by vendors; and will have relative interactions with them (Kang, 2010). Similarly, Parsons (2002) explained that online purchasers love to be considered by sellers and their peers and to be connected with them (Parsons, 2002).

\subsubsection{New Socio-Networking}

New social relations refer to interaction with other buyers, by becoming new friends during purchase process. They communicate with strangers; these interactions could be pleasant (Gutek, 1999). Based on roles theory, most of social interactions are looking for certain patterns in order to accept a role (Solomon et al., 1985). Consumers in a retail environment may undertake to be assistance or request assistance (parker \& Ward, 2000). In addition, mutual interests about fashion and purchase lead to start negotiation with strangers. They negotiate for selecting items to buy, commenting on fashion products or sometimes just for fun, which could lead to talk about other topics (Kang, 2010).

\subsubsection{The Needs of Uniqueness}

Need for uniqueness refers to the need of the individual to be different from others and having distinguished personality (Fromkin, 1971). People with more severe uniqueness are more sensitive toward similarities, they tend to be dissimilar to others and regardless of the risk of social rejection, they exert more individuality (Halpete et al., 2008). Need for uniqueness stimulates a person to distinguish himself from the others by having scarce accessories. Consumers may try to present their uniqueness through their chooses, and they give an idea to their followers (Workman \& Caldwell 2007). Needing to be unique may also appear in buying fashionable clothes. Wearing clothes, in order to show the personality, is one of the ways to be unique; another way is using of goods that are unique and expensive (Fromkin, 1971). If people feel that they are not unique enough, they may do something else like buying clothes according to the fashion to make it up for this unpleasant situation. 


\subsection{Materialism}

Black (1985) describes materialism as the relative importance a consumer attaches to material wealth (Black, 1985). Richens believes that people who are more materialistic will appreciate consuming goods, which are public and social more than the other ones. In fact, for these individuals, the social attitudes of their assets are more important than its own aspect (Hourigan \& Bougoure, 2012). Since fashion clothing makes a frame for a character (Richins \& Dawson, 1992; Black, 1985) and it is a way to show one's identity, (Vieira, 2009) thus, it can be an indicator that shows the relationship of materialism and being involved with fashion.

Browne and Kaldenberg (1997) claimed in their study that there was a causal relationship between materialism and being involved mentally, in which materialism is foreground of the other one. So the people, who have higher levels of materialism, are more obsessed, and spend more energy on activities related to the product and brand. Materialists become more involved with the decision to purchase, since they pay more attention to the property and its appearance; strong and pleasant feelings to the people who possess, spend more time to buying products (Brown \& Kleinberg, 1997).

O'Cass (2004) showed empirical evidence for this subject, and that is, the materialists are concerned with the primary messages sent to attract consumers' fashion clothing, because the information itself is important for them.

\subsection{Fashion mental involvement}

According to Zaichkowsky (1985), mental involvement is described as a person's perception of an object in association with his/her inherent needs, values and interests. He believes various levels of consumer's mental involvement may create different responses to the stimuli and will affect his/her choices. Involvement with the product as one of the main kinds of mental involvement is an ongoing commitment by the consumer, according to the thoughts, feelings and behavioral responses to a kind of product (Quester \& Lim, 2003). Clothing, because of its symbolic role in people's life, is known as a kind of product that induces the higher mental involvement to the consumers.

Some people get the ultimate desirableness from their clothes, and even by thinking about them. To what extent a product can make desirability in a person depends on the extent of mental involvement of that product. Mind involvement with fashion is a perceived interest and dependency from the consumer toward apparel fashion (Kim et al., 2002). Consumers who highly consider clothes, type and its accordance to the fashion have more mind involvement with fashion and always are considered by researchers of consumer behavior and sellers; since these individuals are drivers, influencers, influential people and fans of the process of perceiving fashions (O'Cass, 2000).

According to King, fashion change agents in a society are the consumers who explore changing environment of fashion regularly and are trying to update their clothes according to the prevailing fashions; this factor arises as consumer's mind involvement with fashion apparel (Vieira, 2009). Mind involvement with fashion apparel focuses on the interaction between consumer and fashion apparel as a drive in market. Consequences of mind involvement with products are purchase repetition and use of product, increasing collection of data about the product, high care about the products (Kim et al., 2002). This concept is used for forecasting behavioral variables connected with apparel like purchase behavior and consumers' features (Jordaan \& Simpson, 2006).

Researchers of consumers' behavior believe that mind involvement is a mediator variable in decision making process for purchase and considers it as an interface between consumer and product. Moreover, they found that features of products, consumers and situational factors on purchase decision influence mind involvement (Asadollahi, et al., 2011). In this study mind involvement with 
fashion apparel are considered as an interface in conceptual target of the research and we are seeking to assess the effect of mind involvement on Social shopping behavior of consumers regarding to fashion; on the other hand we considered materialism and need for uniqueness as the aftermaths of mind involvement.

\section{Research hypothesis}

\subsection{Main hypotheses}

$\mathrm{H}_{1}$ : There is a positive and significant relationship between materialism and fashion clothing involvement.

$\mathrm{H}_{2}$ : There is a positive and significant relationship between require to uniqueness and obsessed with fashion garments (fashion clothing involvement).

$\mathrm{H}_{3}$ : There is a positive and significant relationship between Fashion clothing involvement and Social shopping behavior of fashion.

\subsection{Alternative Hypotheses}

$\mathrm{H}_{1-3}$ : There is a positive and significant relationship between Fashion clothing involvement and social browsing.

$\mathrm{H}_{2-3}$ : There is a positive and significant relationship between Fashion clothing involvement and social bounding.

$\mathrm{H}_{3-3}$ : There is a positive and significant relationship between Fashion clothing involvement and opinion showing.

$\mathrm{H}_{4-3}$ : There is a positive and significant relationship between Fashion clothing involvement and power shopping.

$\mathrm{H}_{5-3}$ : There is a positive and significant relationship between Fashion clothing involvement and new socio-networking.

\section{Research Conceptual frameworks}

Regarding to the results of Kang's research social purchase dimensions are in connection with other significant behaviors associated with fashion and socio-psychological components. In this study, we have tried to investigate the impact of mind involvement with fashion apparel on social shopping of fashion apparel. On the other hand, materialism and need for uniqueness are assumed as the backgrounds of such involvement. The present study is descriptive and correlational in terms of practical purpose and the methods of collecting and analyzing data is based on questionnaire. The statistical population includes all people who have lived in city of Tehran, Iran for over 20 years.

The sample size after the pre-test and calculation the variance of the initial sample was 465 patients by using Cochran formula. Using stratified sampling with age pyramid provided by the Iranian Statistics Center 500, questionnaires were distributed, among them, 15 questionnaires were eliminated due to lack of complete information and data analysis was based on 485 questionnaires. The questionnaire uses social shopping behavior based on the method by Kang (2010), Richins and Dawson's (1992) materialism, O'Cass's (2004) mind involvement with fashion apparel and Jirawattananukool \& Tovikkai and also Halepete et al.'s (2009) need for uniqueness, to collect data. This questionnaire includes 32 items, and it was tested via Likert five-point range where 1 means completely disagree, and 5 means completely agree. 


\section{Research methodology}

\subsection{Data analysis}

To test the conceptual model of the research, it is possible to use the method of partial least squares, which is a modeling technique of variance path. This technique provides the situation to investigate the relationship between latent variables and measures (observable variables), simultaneously. Attitude towards the partial least squares has fewer conditions in comparison with structural equation techniques based on covariance such as LISREL. There are two kinds of tests in Partial least squares models: Outer Model and Inner Model. The outer model is similar to the measurement model and inner is like Path Analysis in covariance-based structural equation models. After testing the outer model, it is necessary to investigate the inner model that represents the relationship between latent variables in the study. In this study, due to lack of normal distribution, partial least squares method was used for data analysis.

\subsubsection{Stage I: Assessment of measurement model}

In order to achieve the convergent validity and of correlation rate, compound reliability test and mean of variance was assessed. Reliability greater than 0.7 and mean of variance at least 0.5 are two necessary prerequisites for convergent validity, and correlation for a construct.

Table 1

Evaluation of the measurement model

\begin{tabular}{lccccc}
\hline variable & $\begin{array}{c}\text { Compound } \\
\text { reliability }\end{array}$ & $\begin{array}{c}\text { The mean } \\
\text { Variance }\end{array}$ & variable & $\begin{array}{c}\text { Compound } \\
\text { reliability }\end{array}$ & $\begin{array}{c}\text { The mean } \\
\text { Variance }\end{array}$ \\
\hline Materialism & 0.868 & 0.622 & Social connections & 0.888 & 0.667 \\
Uniqueness requirement & 0.926 & 0.758 & Opinion showing & 0.913 & 0.724 \\
Fashion mental involvement & 0.893 & 0.676 & Power shopping & 0.847 & 0.582 \\
Social browsing & 0.872 & 0.631 & New socio-networking & 0.883 & 0.656 \\
\hline
\end{tabular}

According to above table, compound reliability and convergent validity are approved.

\subsubsection{Second stage: evaluation of structural model}

To test the hypothesis bootstrap method is used in SmartPLS2 software. This algorithm can be built with the help of re-sampling and replacing the original one. To confirm a hypothesis at $95 \%, 99 \%$ and $99.9 \%$, respectively, there is needed to at least about $1.96,2.52$ and 3.32 statistical t.

Table 2

Testing hypothesis

\begin{tabular}{llccc}
\hline & Research hypotheses & The path coefficient & t Statistical & Result \\
\hline $\mathrm{H}_{1}$ & $\begin{array}{l}\text { There is a positive and significant relationship between materialism } \\
\text { and fashion clothing involvement. }\end{array}$ & 0.276 & 6.427 & Acceptable* \\
$\mathrm{H}_{2}$ & $\begin{array}{l}\text { There is a positive and significant relationship between Require to } \\
\text { uniqueness and mental involvement of fashion clothing. }\end{array}$ & 0.480 & 13.293 & Acceptable* \\
$\mathrm{H}_{3}$ & $\begin{array}{l}\text { There is a positive and significant relationship between Fashion } \\
\text { clothing involvement and Social shopping behavior of fashion }\end{array}$ & 0.737 & 32.288 & Acceptable* \\
$\mathrm{H}_{1-3}$ & $\begin{array}{l}\text { There is a positive and significant relationship between Fashion } \\
\text { clothing involvement and social browsing }\end{array}$ & 0.625 & 21.453 & Acceptable* \\
$\mathrm{H}_{3-2}$ & $\begin{array}{l}\text { There is a positive and significant relationship between Fashion } \\
\text { clothing involvement and social bounding }\end{array}$ & 0.636 & 23.476 & Acceptable* \\
$\mathrm{H}_{3-3} \quad \begin{array}{l}\text { There is a positive and significant relationship between Fashion } \\
\text { clothing involvement and opinion showing. }\end{array}$ & 0.708 & 30.507 & Acceptable* \\
$\mathrm{H}_{3-4}$ & $\begin{array}{l}\text { There is a positive and significant relationship between Fashion } \\
\text { clothing involvement and power shopping }\end{array}$ & 0.609 & 24.829 & Acceptable* \\
$\quad \begin{array}{l}\text { There is a positive and significant relationship between Fashion } \\
\text { clothing involvement and social interaction }\end{array}$ & 0.390 & 10.640 & Acceptable* \\
$\mathrm{H}_{3-5}$ & & &
\end{tabular}




\subsection{The results of testing hypotheses}

Based on the results of Table 2, the path coefficients and t-statistics for the first hypothesis is: $\mathrm{t}=6,427$ $\beta=0.276$. Thus, the first hypothesis is confirmed and it shows that there was a positive and significant relationship between materialism and mind involvement. People who are more materialism have higher level of fashion involvement. About the second hypothesis, $(t=0.480 \beta=13.293)$, which shows that there was a positive and significant relationship between mind involvement and uniqueness requirement. It means that people who have higher uniqueness requirement will have higher fashion mind involvement. Verification of the third: $t=32.288 \beta=0.737$ shows that there was a positive and significant relation between mind involvement of fashion clothing and social shopping behavior. People with high level of mind involvement of fashion clothing maintain higher scores in social shopping behavior. We also see that for all other hypotheses, t-student values are greater than 3.32. Therefore, all five hypotheses have been confirmed in level of $99.9 \%$ and all dimensions of social shopping behavior have positive and significant relation with cloth fashion mind involvement.

\section{Conclusion}

Findings from the data analysis imply that the need for uniqueness has the great impact on fashion clothing involvement. Need for uniqueness may appear in fashion apparel. One of the ways of uniqueness is to wear unique clothes and it shows the personality of the consumer; if individuals do not have enough own uniqueness feeling, such feeling make them to do activities like buying clothes according to new fashions to compensate for this unfortunate situation. This type of consumers require more freshness and complexity, therefore it shows more levels of mind involvement and with fashion apparel. The results of this assumption are match with previous researches (Halepete et al., 2009). Another effective component on mind involvement with fashion apparel is materialism. People who are more materialistic give more value to the goods consumed socially and obviously; the fashion apparel is categorized in this type of products. According to materialistic people since they pay more attention on ownership and appearance, they get more involved with fashion apparel, which confirms most of previous researches (O'Cass, 2001, 2002, 2004; Browne \& Kaldenberg, 1997; Hourigan \& Bougoure, 2012).

On the other hand, the conceptual model of the research, Fashion social shopping behavior has been studied by its five dimensions as the consequences of mind involvement with fashion apparel. Results have shown that people with higher levels of fashion clothing involvement feel more need for exchange of information about fashion, and have social interactions. In the meantime, fashion clothing involvement with fashion apparel has the most impact on opinions. Consumers with high level of mind involvement believe when they wear new type of clothes and share their purchase information with others, they get praised by them. They are interested in influencing others by interpersonal conversations with others. Three factors of social pursuit, social ties and purchase afford in terms of rate of being influenced from mind involvement with fashion apparel is placed in next order and in terms of the intensity of the relationship with mind involvement and the greatness of regression coefficient approximately are at the same level.

Consumers with higher level of mind involvement with fashion apparel search for information about fashions and the popular products among others. Awareness about what others buy, direct them in decision making of what to purchase. These individuals during purchase devote more time for togetherness and interactions with close friends and family, these interactions inspire the consumers' positive feelings of pleasure, entertainment and recreation. Consumers with higher levels of mind involvement tend to be considered by sellers and to have relation with them, to feel respected and strength. 
New social relations as the fifth dimension social shopping behavior have a direct relation with the level of mind involvement. People, who have more mind involvement with fashion apparel, tend more to make new friends during purchase process. No direct research about the relation between mind involvement with fashion apparel and fashion social shopping behavior has been done. Some of previous researches studies indirectly about the impacts of mind involvement with fashion apparel on some components of fashion social shopping behavior. Later, we will point out some of them. Tigert (1976) believes that consumers who have high mind involvement with fashion apparel are highly considerable in fashion industry. They are the leaders of fashion and the first people who try the products and have personal relations about fashion. In another research, four components of pleasure seeking identity of the buyer, ongoing search for information, spokesperson in the market were considered as the consequences of mind involvement with fashion apparel (Hourigan \& Bougoure, 2012); which can the seal of approval on all sub-hypothesis of the present research.

\section{Acknowledgement}

The authors would like to thank the anonymous referees for constructive comments on earlier version of this paper.

\section{References}

Arnold, M. J., \& Reynolds, K. E. (2003). Hedonic shopping motivations. Journal of Retailing, 79, 77 95.

Ghafelehbashi, S., Asadollahi, A., \& Nikfar, F. (2011). Acquaintance with all types of involvement in consumer behavior. Interdisciplinary Journal of Contemporary Research in Business, 3(5), 493 507.

Babin, B. J., Darden, W. R., \& Griffin, M. (1994). Work and/or fun: Measuring hedonic and utilitarian shopping value. Journal of Consumer Research., 20(4), 644-656.

Belk, R. (1985). Materialism: trait aspects of living in a material world. Journal of Consumer Research, 12, 265-280.

Bertrandias, L., \& Goldsmith, R. E. (2006). Some psychological motivations for fashion opinion leadership and fashion opinion seeking. Journal of Fashion Marketing and Management, 10(1), 25-40.

Bloch, P. H., Ridgway, N. M., \& Dawson, S. A. (1994). The shopping mall as consumer habitat. Journal of retailing, 70(1), 23-42.

Bloch, P. H. (1995). Seeking the ideal form: product design and consumer response. Journal of marketing, 59(3), 16-29.

Browne, B. A., \& Kaldenberg, D. O. (1997). Conceptualizing self-monitoring: links to materialism and product involvement. Journal of Consumer Marketing,14(1), 31-44.

Burns, D. J., \& Warren, H. B. (1995). Need for uniqueness: shopping mall preference and choice activity. International Journal of Retail \& Distribution Management, 23(12), 4-12.

Chang, E., Burns, L. D., \& Francis, S. K. (2004). Gender differences in the dimensional structure of apparel shopping satisfaction among Korean consumers: The role of hedonic shopping value. Clothing and Textiles Research Journal, 22(4), 185-199.

Cowan, R., Cowan, W., \& Peter Swann, G. M. (2004). Waves in consumption with interdependence among consumers. Canadian Journal of Economics/Revue canadienne d'économique, 37(1), 149177.

Dawson, S., Bloch, P. H., \& Ridgway, N. M. (1990). Shopping motives, emotional states, and development and validation. Journal of Consumer Research, 28(1), 50-66.

Flynn, L. R., Goldsmith, R. E., \& Eastman, J. K. (1996). Opinion leaders and opinion seekers: two new measurement scales. Journal of the Academy of Marketing Science, 24(2), 137-147. 
Fromkin, H. L. (1971). A social psychological analysis of the adoption and diffusion of new products and practices from a uniqueness motivation perspective. In Proceedings of the second annual conference of the Association for Consumer Research (pp. 464-469).

Goldsmith, R. E., \& Clark, R. A. (2008). An analysis of factors affecting fashion opinion leadership and fashion opinion seeking. Journal of Fashion Marketing and Management, 12(3), 308-322.

Gutek, B. A. (1999). The social psychology of service interactions. Journal of Social Issues, 55(3), 603-617.

Halepete, J., Littrell, M., \& ,.Park, J., (2009), Personalization of fair trade apparel. Clothing and Textiles Research Journal, 27(2), 143-160.

Holahan, C. (2007). Hanging out at the e-mall, Business Week Online. 6.

Hourigan, S. R., \& Bougoure, U. S., (2012), Towards a better understanding of fashion clothing involvement. Australasian Marketing Journal, 20, 127-135.

Jordaan, Y., \& Simpson, M. N. (2006). Consumer innovativeness among females in specific fashion stores in the Menlyn shopping centre. Journal of Family Ecology and Consumer Sciences= Tydskrif vir Gesinsekologie en Verbruikerswetenskappe, 34, p-32.

Kang, J. (2010). Social shopping for fashion. Poaps, P. H., Louisiana State University, The School of Human Ecology.

Kim, H. S., Damhorst, M. L., \& Lee, K. H. (2002). Apparel involvement and advertisement processing: A model. Journal of Fashion Marketing and Management, 6(3), 277-302.

Lerkpollakarn, A., \& Khemarangsan, A., (2007). A study of Thai consumer behavior towards fashion clothing. International Business Program, Silpakorn University.

Murray, H.A. (1938). Explorations in personality, New York, NY: Oxford University Press, 531-545.

O'Cass, A. (2000). An assessment of consumers product, purchase decision, advertising and consumption involvement in fashion clothing. Journal of Economic Psychology, 21(5), 545-576.

O'Cass, A. (2004). Fashion clothing consumption: antecedents and consequences of fashion clothing involvement. European Journal of Marketing,38(7), 869-882.

Parker, C., \& Ward, P. (2000). An analysis of role adoptions and scripts during customer-to-customer encounters. European Journal of Marketing, 34(3/4), 341-359.

Parsons, A. G. (2002). Non-functional motives for online shoppers: why we click. Journal of Consumer Marketing, 19(5), 380-392.

Phau, I., \& Lo, C. C. (2004). Profiling fashion innovators: A study of self-concept, impulse buying and Internet purchase intent. Journal of Fashion Marketing and Management, 8(4), 399-411.

Piacentini, M., \& Mailer, G. (2004). Symbolic consumption in teenagers' clothing choices. Journal of Consumer Behaviour, 3(3), 251-262.

Quester, P., \& Lim, A. L. (2003). Product involvement/brand loyalty: is there a link?. Journal of product \& brand management, 12(1), 22-38.

Reynolds, K. E., \& Beatty, S. E. (2000). A relationship customer typology.Journal of retailing, 75(4), 509-523.

Richins, M., \& Dawson, $\quad$ S. (1992). A consumer values orientation for materialism and its measurement: scale development and validation. Journal of Consumer Research, 19(2), 303-316.

Rogers, E. M. (1976). New product adoption and diffusion. Journal of consumer Research, 2(4), 290301.

Solomon, M. R., Surprenant, C., Czepiel, J. A., \& Gutman, E. G. (1985). A role theory perspective on dyadic interactions: The service encounter. Journal of marketing, 49(1), 99-111.

Stone, G. P. (1954). City shoppers and urban identification: Observations on the social psychology of city life. The American Journal of Sociology, 60(1), 36-45.

Tian, K. T., Bearden, W. O., \& Hunter, G. L. (2001). Consumers' need for uniqueness: Scale development and validation. Journal of consumer research,28(1), 50-66.

Tovikkai, K., \& Jirawattananukool, W. (2010). An exploratory study on young Thai women consumer behavior toward purchasing luxury fashion brands.

Vieira, V. A. (2009). An extended theoretical model of fashion clothing involvement. Journal of Fashion Marketing and Management, 13(2), 179-200. 
1210

Westbrook, R. A., \& Black, W. C. (1985). A motivation-based shopper typology. Journal of Retailing, 61(1), 78-103.

Workman, J. E., \& Caldwell, L. F. (2007). Centrality of visual product aesthetics, tactile and uniqueness needs of fashion consumers. International Journal of Consumer Studies, 31(6), 589596.

Zaichkowsky, J. L. (1985). Measuring the involvement construct. Journal of Consumer Research, 12 , 341-352. 